\title{
Virtual autopsy in forensic sciences and its applications in the forensic odontology
}

\section{A autópsia virtual nas ciências forenses e sua aplicação na Odontologia forense}

\begin{abstract}
Nowadays, technological advances are becoming more and more important in forensic sciences. Yet autopsy is still one of the very traditional methods. This also applies for dentalautopsies, in which visual, photographic and radiological evidences are collected. In this context, Virtual Autopsy appears as a helpful and complementary tool for dental and medical cadaveric examination. Usinghigh-tech radiological approaches, Virtual Autopsy may provide, through images, an efficient and more accurate view on the individual case. This critical review aims to update the dental professionalspresenting the first national paper with explanations on Virtual Autopsy.
\end{abstract}

Keywords: Autopsy; Radiology; Forensic Odontology; Forensic Medicine

\section{Resumo}

Atualmente os avanços tecnológicos se fazem cada vez mais importantes nas ciências forenses. Por outro lado a autópsia ainda é uma abordagem tradicional na prática médica-odontológica, na qual evidências são coletadas por meio fotográfico e radiológico. Neste contexto, a Autópsia Virtual surge como uma ferramenta útil e complementar para o exame cadavérico. Através da alta tecnologia radiológica a Autópsia Virtual fornece uma visão eficiente e precisa do caso a ser analisado. Esta revisão crítica tem o objetivo de atualizar os Cirurgiões-dentistas apresentando o primeiro trabalho com o conteúdo voltado a Autópsia Virtual.

Palavras-chave: Autópsia; Radiologia; Odontologia Legal; Medicina Legal

\author{
Ademir Franco do Rosário Junior a \\ Paulo Henrique Couto Souza ${ }^{b}$ \\ Walter Coudyzer ${ }^{\mathrm{C}}$ \\ Patrick Thevissen ${ }^{a}$ \\ Guy Willems a \\ Reinhilde Jacobs ${ }^{c}$
}

- Forensic Odontology, Department of Oral Health Sciences, Katholieke Universiteit Leuven, Leuven, Belgium

${ }^{\mathrm{b}}$ Department of Stomatology, PontificalUniversity Catholic of Parana, Curitiba, PR, Brazil

c Oral Imaging Center, Department of Oral Health Sciences, Katholieke Universiteit Leuven, Leuven, Belgium

\author{
Correspondence: \\ Ademir Franco do Rosário Junior \\ Remi Vandervaerenlaan, 1 - 0301 \\ 3000 Leuven - Belgique \\ E-mail: franco.gat@gmail.com
}

Received: February 2, 2012

Accepted: March 21, 2012

Conflict of Interests: The authors state that there are no financial and personal conflicts of interest that could have inappropriately influenced their work.

Copyright: (C) 2011 Franco et al.; licensee EDIPUCRS This is an Open Access article distributed under the terms of the Creative Commons AttributionNoncommercial-No Derivative Works 3.0 Unported License. 


\section{Introduction}

Although forensic sciences were improved by the introduction of new imaging techniques, during forensic autopsies the cause of death continues to be investigated based on traditional methods of dissecting, describing and documenting (1).

The "medico-legal autopsy" often referred to as "medicolegal necropsy" is considered the most important forensic expertise, and therefore it is even called "the expertise of expertises" (2). According to the Dictionary of Legal Medicine proposed by Manif and Elias Zacharias (2), its execution includes the examination of the body, externally and internally, considering the thanatology as the main goal to diagnose. The etymology of "autopsy" refers to the doctor examining a body, and the union of the terms "autos" and "psia" meaning "own" and "view" respectively (3-5).

The traditional internal autopsy procedure consists of body mutilating techniques. Due to the emotional aspects of the victim's relatives, their knowledge of these mutilation forms the major objection against autopsies (4). The arguments justifying the autopsy, namely the need to know the cause of death or the identity of an unknown deceased individual overrules this emotional involvement. Therefore, the families and relatives of the victim often remain in a conflicting situation with the forensic examiners (6). Parallel to that, some religious and cultural aspects represent relevant objections for the autopsy procedure. An exampleis observed in religious strands, such as Judaism, where it is not permitted to undergo the process of autopsy $(7,8)$.

Based on these objections, and in an attempt to ameliorate the autopsy results, alternative aids in diagnosing the cause of death were developed. One of these is radiological imaging. Its use for medico-legal purposes was seen in the forensic practice since 1896. Martin and Arroio (9) showed the applicability of post-mortem radiographic techniques in order to identify bodies through comparative analysis of the cranial sinuses. Besides, numerous cases were reported in which liver, heart, brain and bone injuries were investigated radio graphically revealing the possible death cause(s) $(10,11)$. Furthermore, X-ray examinations were valuable to perform guided autopsies based on the acquired skeletal information. More specific in detecting(healing) bone fractures, which in many cases are indistinguishable during traditional autopsy $(9,12,13)$.

A new autopsy technique consists of the internal examination of death bodies using computed tomography (CT) and magnetic resonance imaging (MRI), without opening the body or body parts. Besides, it allows the reconstruction of a $3 \mathrm{D}$ view of the analyzed cadaver. This procedure was called "Virtopsy ${ }^{\circledR}$ " (Virtopsy Project ${ }^{\circledR}$, Zurich, Switzerland), which was derived from the words "virtual" (Greek: virtus: effective) and "autopsy" (Greek: autos: own + opsomei: to see) $(8,14-16)$.

Because the dentition contains multiple identifiers teeth often play a major role in human identification processes (17). Three processes allow for dental identification: the comparison between post mortem (PM) and ante-mortem (AM) data, the development of dental PM victim profiles and the dental DNA techniques (18). The collection of all PM dental data is indispensable for dental identification. These are obtained by direct visual observation and related recording of the available evidence. Additional information is collected after photographic and radiographic imaging of the dentition and the oral cavity. In certain cases the PM photographic and radiological exam is difficult because the access to the oral cavity is hindered (e.g. bodies in rigor mortis condition).In contrast to the classical dental autopsy the virtual autopsy process allows dental identification in an accurate and quick way without damaging the body to access the available dental data (19). Dental age estimation methods based on tooth development can be applied during the virtual autopsy, allowing the examiner to include or exclude individuals based on age related victim lists.

Based on the above, this study aims to update forensic odontology professionals, on the virtual autopsy process and more specific on the applications of this technology related to dental ID and associated dental age estimations.

\section{Origin and mechanisms}

In 1970 the journal "Chest" released the following headline: "The autopsy: Do we still need it?" This question suggested the initiation of new paths and alternative ways for autopsy (20). The most important pathway was provided by imaging techniques and was supported by the creation of organizations like the Institute of Forensic Medicine (Denmark), the Victorian Institute of Pathology (Australia), the Society of Imaginological Autopsy (Japan) and the Headquarters of Medical Examinations of the Armed Forces of the United States of America (21). In the nineties, the Institute of Forensic Medicine of the University of Bern, Switzerland, began to document on the characteristics of the human body in a concrete, objective and non-invasive way. This resulted in the creation of a new discipline, denoted as "Virtopsy", a virtual project of autopsy (1). In this context, the concept of the objective and noninvasive documentation of the body consists in the observation of the anatomical structures through computed tomography (CT), magnetic resonance (MRI) and micro radiology devices. Specific software (e.g. Tera Recon Aquarius NET ${ }^{\circledR}$, Foster City, California, United States of America) allowed for 3D reconstructions of the computed tomography images from the observed structures. Another part of the documentation concerns the body surface recording, performed by forensic photogrammetric and 3D optical scanning (21).

Due to the need of getting quick and accurate information about forensic cases, international researches increasingly indicate Virtual Autopsy as a useful tool for forensic exams. Ebert et al. (15) specified that 3D reconstructions made the examination processes more efficient and could be carried out and interpreted (1) by a single specialized examiner.

Aiming the CT exam, the body can remain wrapped in an artifact-free body bag (Rudolph Egli $\mathrm{AG}^{\circledR}$, Bern, 
and Switzerland), and several exam protocols can be chosen considering the area to be analyzed. For soft tissue investigation the magnetic resonance is the best choice due to its dependence from the hydrogen molecules. The internal image collection is carried out on radiological units, e.g. the Leonardo ${ }^{\circledR}$ workstation (Siemens Medical Solutions ${ }^{\circledR}$, Erlangen, Germany) (13). The external examination is performed using the GOM TRITOP/ATOSIII ${ }^{\circledR}$ system $\left(\mathrm{GOM}^{\circledR}\right.$, Braunschweig, Germany) (15). The TRITOP portion is based on photogammetry, therefore digital images are taken by a Nikon D2X ${ }^{\circledR}$ camera (Nikon Corp. ${ }^{\circledR}$, Tokyo, Japan) and submitted wirelessly to the main system (15). Through these images the photogammetry calculates the position of the body and the texture of the surface model. The surface scanning is performed by the ATOS component, and it is based on the principle of triangulation (15). The sensor head has one camera on each side and a projection unit in the middle, the images taken are transferred to the computer and the 3D surface points are calculated (15). The whole procedure to scan for example both jaws with high image quality takes, depending on the used protocol, around 1 minute (19).

Aiming the management and organization of the Virtual Autopsy data, several software packages are implemented during the data acquisition. Such as the navigation software for Muti-slice CT analysis and the TRITOP/ATOS ${ }^{\circledR}$ software for surface scanning and photogammetry. These packages are controlled remotely by the Virtopsy Control Centre - VCC ${ }^{\circledR}$ (PROFACTOR Gmbh ${ }^{\circledR}$, Steyr-Gleink, Austria), the main single software which sets all the robotic positions, guides the operator and stores the entire patient's information. Another complementary system is the Virtopsy Robot Control - VRC ${ }^{\circledR}$ (PROFACTOR Gmbh ${ }^{\circledR}$, Steyr-Gleink, Austria), which is responsible for executing the commands related to mobile tools, such as the robotic arms which perform scanning procedures (15).

\section{Effectiveness}

Because of the fact that different areas require specific imaging techniques, the precision of virtual autopsy on detailing anatomical structures depends, mainly, on the equipment and settings used. Mostly, the research protocols follow Computed Tomography for hard tissues, Magnetic Resonance for soft tissues and combination of both for differentiation between adjacent structures. Cha et al. reported that $80 \%$ of causes of death diagnosed by the traditional method were also found by the virtual approach (1). Yen et al. (5) detected a high potential of accuracy using 57 bodies. The authors verified that in the CT scan, the presence of fracture lines was noted, which was not commonly found in traditional autopsy. Despite of that, they indicated that both virtual and traditional techniques should be applied complementary, because information about color, smell and sometimes texture can be lost on restricted virtual exams (5). Aghayev (12) observed full agreement between coincidental points with virtual and traditional autopsy techniques. This author used computed tomography to examine a victim of trampling. It was possible to analyze lesions of difficult access in the base of the skull. Bruck et al. (10) reported a similar case, in which an accident involving a pedestrian and vehicle was described. In these cases it was essential to differentiate primary and secondary lesions. The first type of injury is inflicted by the contact of the vehicle and the victim and the second type between the victim and asphalt. With high accuracy and in a short time the technique of magnetic resonance was used to locate the primary and secondary traumas. Ampazoni et al. (13) cites the advantage to obtain information about the depth of trauma from sharp instruments, as well as detailed data of micro bone injuries.

Ethical objections against the virtual technique advocate the data privacy of the examined corpses. Aghayev et al. (14) explain that the privacy security is accomplished through an operational program that guarantees anonymis ation prior to transfer of the considered data $(15,17)$.

\section{Virtual Autopsy applications}

The Virtual Autopsy can be applied in a broad number of forensic situations, such as thanatological investigations; carbonized and putrefied body identifications; mass disaster cases; age estimation; anthropological examinations and skin lesion analyses.

In drowned bodies the $\mathrm{CT}$ information about the volume, density, size of the lungs and the amount of liquid observed in them is helping in diagnosing the cause of death (11).

Cases of firearm projectile injuries are often difficult to examine because either sometimes the bullet is not in the body, or diverted by an anatomical structure, or it can be in unknown body parts. Therefore, knowing the location of the projectile before the autopsy is performed facilitates the examination (22).

In mass disaster cases Dirnhofer et al. (21) describe for human identification purposes the use of adapted vehicles (e.g. Oshkosh Specialty Vehicles ${ }^{\circledR}$, Clearwater, Florida, United States of America) with imaging machines allowing for PM data collection on the disaster field. The author states that mobile CT imaging could provide a high level of positive identifications.

In the odontology field, Oesterhelweg et al. (23) describe a case where the victim was struck by respiratory obstruction from a foreign body (food bolus). The differentiation of the obstructive structure was performed with combined computed tomography and magnetic resonance imaging. In conventional autopsy examinations the greatest difficulty is to predict the depth of the foreign body. The virtual autopsy provides this information accurate and clear. Health professionals must be aware of these complementary exams because over $90 \%$ of these emergency cases were misdiagnosed.

Another specific odontological application for the Virtual Autopsy is on the comparison between AM orthopantomograms and PM reconstructed panoramic 
overviews of cranial CT images. This way PM dental evidences can easily be related to the AM data of the expected missing person (21). Birngruber et al. (24) reported a positive identification case based on the superimposition of post-mortem CT reconstructed images on ante-mortem radiographies.

Dedouit et al. (25) stressed the importance of the presence of dentists in the forensic identification teamin particular to determine the age of charred bodies. In traditional medical examinations the decomposition of the body is a limiting factor for age assessments. Therefore, the author cites the performance of dentists to examine dental and anthropological data $(25,26)$. Other studies $(27-29)$ also relate the role the forensic Odontologist on age estimations. Through the CT analysis of the Australian bushfire victims, the forensic experts obtained substantial information for human identification based on age estimation techniques.

Studies on restorative materials are also related on the virtual technique. Through the analysis of the restoration materials density, Jackowski et al. (19) performed pioneering researches on Odontology in Virtual Autopsy. These authors expressed in Hounsfield Units the different density of restoration materials, such as composites, temporary fillings and ceramics, by ultra-high-resolution CT imaging. Furthermore, the author verified the course of restoration materials under high temperatures by $\mathrm{CT}$ images, simulating a fire mass disaster (30).

\section{Final considerations}

As observed nowadays, the incidence of invasive Odontological treatments is decreasing, making the dental identification based on restorative materials more difficult. Therefore the forensic dentist can improve the forensic examinations analyzing detailed morphological structures of the teeth, e.g. pulp chamber shapes, roots arrangement and periodontal status.

Virtual autopsy emerges as a useful tool for forensic investigations. Its main benefits are related to the improved collection of data compared to the traditional technique. The feasibility of visualizing 3-D anatomical structures thoroughly, in real time, without damaging the body is an important gain. The absence of contamination from cadaver's substances is an additional advantage. The review of the case even after several years of death, the disposal of radiological chemical processing and the improved data organization and communication are benefits provided by the computed approach present in the virtual autopsy.

The main objection observed in the application of virtual autopsy, is its support to be performed in less developed countries, in which high-technological imaging devices are not easily feasible for scientific purposes. Despite that, the bioethical issue related to the digital imaging transferring is another objection for the use of virtual autopsy. However, as any other new trend in science, the virtual autopsy is still developing and getting space among the commonly used methods.

This review allows concluding that the virtual autopsy favors the development of forensic autopsies. However, the professional knowledge is not expendable or replaceable by high-technology methods, but summable. This articles hopes to stimulate multidisciplinary research to develop improved tools and protocols for virtual autopsy and to stress the role of forensic Odontologists in this field.

References 1. Cha JG, Kim DH, Kim DH, Paik SH, Park JS, Park SJ et al. Utility of postmortem autopsy via whole-body imaging: Inicial observations comparing MDCT and 3.0T MRI findings with autopsy findings. Korean J Radiol 2010;1 1:395-406.

2. Zacharias $M$, Zacharias E. Dicionário de medicina legal. $2^{a}$ ed. Curitiba: Editora Universitária Champagnat; 1991.

3. Almeida JR A, Costa JR JBO. Lições de medicina legal. 20ª ed. São Paulo: Editora Nacional; 1991

4. França GV. Medicina legal. $5^{a}$ ed. Rio de Janeiro: Guanabara Koogan; 1998.

5. Yen K, Lövblad KO, Scheurer E, Ozdoba C, Thali MJ, Aghayev E et al. Postmortem forensic neuroimaging: correlation of MSCT and MRI findings with autopsy results. Forensic Sci Int. 2007;173:21-35.

6. Maldonado MT. Psicologia da gravidez. 17 ed. São Paulo: Saraiva; 2009.

7. Lamm M. Autópsia e embalsamento segundo a lei judaica. [Online News]. [Accessed on 2011 April 17]. Available at http://www.dihitt.com.br/n/religiao/201 1/03/29/autopsiae-embalsamamento

8. Pomara C, Fineschi V, Scalzo G, Guglielmi G. Virtopsy versus digital autopsy: virtuous autopsy. Radiol Med 2009;1 14:1367-82.

9. Martin A, Arroio J. La radiologia cadavérica. Rev Esp Med Legal 1986;1:46-7.

10. Bruck U, Christe A, Naether S, Ross S, Thali MJ. Virtopsy - non invasive detection of occult bone lesions in postmortem MRI: Additional information for traffic accident reconstruction. Int J Legal Med. 2009;123:221-6.

1 1. Levy AD, Harcke HT, Getz JM, Mallak CT, Caruso JL, Pearse L et al. Virtual autopsy: Two and three dimensional multidetection CT findings in drowning with autopsy comparison. Radiology 2007;243:862-8. 
12. Aghayev E, Thali M, Jackowski C, Sonnenschein M, Yen K, Vock P et al. Virtopsy - Fatal motor vehicle accident with head injury. J Forensic Sci 2004;49:1-5.

13. Ampanozi G, Ruder TD, Preiss U, Aschenbroich K, Germerott T, Filograna L et al. Virtopsy: CT and MR imaging of a fatal head injury caused by hatchet: A case report. Legal Med 2008; 12:238-41.

14. Aghayev E, Staub L, Dirnhofer R, Ambrose T, Jackowski C, Yen K et al. Virtopsy - the concept of a centralized database in forensic medicine for analysis and comparison of radiological and autopsy data. J Forensic Leg Med 2007;15:135-40.

15. Ebert LC, Ptacek W, Naether S, Fürst M, Ross S, Buck U et al. Virtobot-a multi-functional robotic system for 3D surface scanning and automatic post mortem biopsy. Int J Med Robotics Comput Assist Surg 2010;6:18-27.

16. Thali MJ, Ross S, Oesterhelweg L, Grabherr S, Buck U, Naether S et al. Virtopsy - working on the future of forensic medicine. Rechtsmedizin 2007;17:7-12.

17. Thali MJ, Jackowski C, Oesterhelweg L, Ross S, Dirnhofer R. Virtopsy - the swiss virtual autopsy approach. Leg Med 2007;9:100-4.

18. Girish KL, Rahman FS, Tlppu SR. Dental DNA fingerprinting in identification of human remains. J Forensic Dent Sci 2010;2:63-8.

19. Jackowski C, Wyss M, Persson A, Classens M, Thali MJ, Lussi A. Ultra-high-resolution dual-source $C T$ for forensic dental visualization - discrimination of ceramic and composite fillings. Int J Legal Med 2008;122:301-7.

20. Edwards JE. The autopsy: Do we still need it? Chest 1970; 57:113-4.

21. Dirnhofer R, Jackowski C, Vock P, Potter K, Thali MJ. Virtopsy - minimally invasive, imaging guided virtual autopsy. Radio Graphics 2006;26:1305-33.

22. Levy AD, Abbott RM, Mallak CT, Getz JM, Harcke HT, Champion HR, Pearse LA. Virtualautopsy - Preliminary experience in high-velocity gunshot wound victims. Radiology 2006;240:522-8.

23. Oesterhelweg L, Bolliger SA, Thali MJ, Ross S. Postmortem imaging of laryngeal foreign bodies. Arch Pathol Lab Med 2010;133:806-10.

24. Birngruber CG, Obert M, Ramsthaler F, Kreutz K, Verhoff MA. Comparative dental radiographic identification using flat panel CT. Forensic Sci Int $2011 ; 209: 31$-4.

25. Dedouit F, Telmon N, Costaglioga R, Otal P, Joffre F, Rougé D. Virtual anthropology and forensic identification: Report of one case. Forensic Sci Int 2007;1 173:182-7.

26. Dedouit F, Telmon N, Guilbeau-Frugier C, Gainza D, Otal P, Joffre F, Rougé D. Virtual autopsy and forensic identification - practical application: are port of one case. J Forensic Sci 2007;52:960-4.

27. Bassed RB, Hill AJ. The use of computed tomography (CT) to estimate age in the 2009 Victorian Bushfire Victims: a case report. Forensic Scilnt 2011 ;205:48-51.

28. O'donell C, Lino M, Mansharan K, Leditscke J, Woodford N. Contribution of post mortem multidetector CT scanning to the identification of the deceased in a mass disaster: experience gained from the 2009 Victorian bushfires. Forensic Sci Int 2011 ; 205:15-28.

29. Cordner SM, Woodford N, Bassed R. Forensic aspects of the 2009 Victorian Bushfires Disaster. Forensic Sci Int 2011 ;205:2-7.

30. Woisetschläger $M$, Lussi A, Persson A, Jackowski C. Fire victim identification by postmortem dental CT: Radiologic evaluation of restorative materials after exposure to high temperatures. Eur J Radiol $2011 ; 80: 432-40$. 